\title{
Teachers of secondary school as Democracy Coaches: Study of their conceptions during their initial formation
}

\author{
Mario Ferreras-Listán ${ }^{1, *}$, José Antonio Pineda-Alfonso ${ }^{1}$, and Elena Guichot-Muñoz ${ }^{2}$ \\ ${ }^{1}$ University of Seville, Didactics of Experimental and Social Sciences Department, Calle Pirotecnia, \\ s/n. 41013-Sevilla. España. \\ ${ }^{2}$ University of Seville, Didactics of Language and Literature and Integrated Philologies Department, \\ Calle Pirotecnia, s/n. 41013-Sevilla. España.
}

\begin{abstract}
This study has been developed within the framework of a European Erasmus + project called ELEF $\dagger$. The aim of this project is to develop, implement, evaluate and replicate innovative democratic learning environments. With this purpose, the Democracy Coaches are trained as agents of citizen participation and generators of democracy, both in educational centres and in informal educational settings. In this context, and during various training sessions, the Democracy Coaches work with the knowledge and skills they need to acquire. This paper focuses on the study and analysis carried out on the concepts expressed by these teachers of secondary education during their training. In order for them to become democracy coaches in the formal educational field, we address concepts such as democracy, citizenship and the most appropriate teaching-learning methodology for illustrating these concepts and competences, bearing in mind that they should educate citizens with full awareness of their rights and duties.
\end{abstract}

\section{Introduction}

The European countries, following the recommendations of the Council of Europe, have faced the responsibility of transmitting to young people the civic, democratic and pluralistic values shared by the European society. The public education (of any democratic community) has the obligation to enable its citizens to participate actively in civil and political society without the risk of exclusion. Therefore, being a citizen requires an adequate training in the structuring of a participatory democracy, autonomously and in accordance with the society and culture in which we are situated. No democracy is possible without the active participation of citizens. Democracy is the political system that recognizes and respects human and social rights and demands political and legal duties.

\footnotetext{
*Corresponding author: mferreras@us.es

$\dagger$ ELEF: European Learning Environment Formats for Citizenship and Democracy, Reference number 580426 .
} 
From the European Erasmus + project called ELEF (European Learning Environment Formats for Citizenship and Democracy), three different formats of innovative democratic learning environments will be implemented, developed, evaluated and replicated. These three formats have been piloted by the University of Bremen as project coordinator.

One of the three forms of innovative democratic learning environment is limited to the formal education field. In this field, students of the University Master's degree in Teaching in Compulsory Secondary Education and Baccalaureate, Vocational Training and Language Teaching (MAES, from University of Seville, Spain) are trained to be Democracy Coaches, a figure that promotes the development of democratic competence in schools. Especially, this format addresses the need to support teachers and educators in conflict resolution and student diversity. It therefore focuses on the training of future teachers to improve democratic competence and conflict resolution of teachers and pupils in secondary schools. The didactic approach is based on introducing and implementing research and exploration learning approaches in the curriculum (and in the context of didactic projects). The purpose of this action is to encourage students and teachers to develop a learning approach based on reflection, practice, participation, autonomy and criticism, to develop a better understanding and reflection on society. This provides an innovative learning approach for students and an innovative teaching methodology for future teachers who will soon join the education system. After a comprehensive training, these future teachers are expected to take these methods to their professional practices in secondary schools, high schools and vocational trainings, where they will work as Democracy Coaches directly with the students.

Democracy must be based on the laws that regulate the coexistence of people, as well as on a political culture that makes it possible. To this end, this democracy must be promoted through education. Therefore, the understanding of democracy depends not only on the laws, but also on the democratic competencies, attitudes and values shared by its citizens.

According to Bolívar[1], civic virtues, which make it possible to live in common in a democracy, are transferred through education. If we want to preserve democracy alive, the first challenge is to educate for active citizenship. Therefore, exercising citizenship requires an adequate level of education, which is necessary to implement a real democracy and to participate in it autonomously and coherently.

Democratic education must promote the active participation of citizens in all areas of their personal development, especially in school, since it is in this context (together with the family) that individuals are trained as individuals and as citizens. That is why we understand democracy, in the broad sense, as a way of life, rather than merely a procedure for electing representatives to take political decisions, to govern our existence. Democratic education has an educational value and should encourage participation in all the school areas: school and classroom management, coexistence, etc. It must be present in the basic decisions that determine the very nature of the school and the curriculum.

In this paper the conceptions on democracy and democracy perception of forty students of the MAES (from Spain) are collected and analysed. Among other issues, students have been asked on how democracy in schools can be studied, by creating a more democratic environment, or what relationship is established between democracy and education for citizenship. Of course, all these students took a BA prior to the MA.

In order to know the believes of these future teachers, we have sent them a questionnaire of ten questions, in which each one has exposed his/her personal opinion. Subsequently, a Focus Group has been set up to discuss the responses obtained. 


\section{Methodology}

\subsection{Design and procedure}

As mentioned above, one of the objectives of this research is to learn about the conceptions that future secondary school teachers have of the teaching and learning active democracy in education, through a questionnaire.

To this end, we can indicate that the design of the research corresponds to a nonexperimental, systematic and empirical design in which the independent variables are not manipulated because they have already happened, conceived to capture respondents' perceptions. According to Hernández, Fernández and Baptista[2] the inferences about the relationships between variables are made without direct intervention or influence. It is also a cross-sectional, descriptive design by analyzing the status of various variables at a given time, when the instrument was applied, and the data collected. The purpose is to describe variables and analyze their incidence and interrelation at the time of the study. The phenomenon under study is worked on in its natural context (training classes in the MAES). The research has a quantitative approach because the data from the surveys were quantified.

\subsection{The sample}

The sample of the study was made up of 40 students belonging to the University Master's Degree in Teachers of Compulsory Secondary Education and Baccalaureate, Vocational Training and Language Teaching (MAES). These students have been selected because they have taken the subject of "Education for Citizenship" which is an optional subject with a total duration of 40 hours. The heterogeneity of the degree of the students, is very diverse such as History and Geography, English and French Philology, Architecture, Journalism, Biology, etc.

\subsection{Instruments}

In this research, the instrument used to collect the information was an eight-question questionnaire, which was developed within the project by the researchers. The procedure to determine the validity of the research instruments consisted of handing over the questionnaire and the system of categories to three professionals from the University of Seville, experts in the field. An expert in methodology, design and construction also validated the questionnaire. The experts made the necessary and relevant corrections to the ambiguities of form or content they found in the instruments. These eight questions attempt to answer three different dimensions or categories: the first category is the conceptualization of democracy (questions 1,2 and 3), the second is how democracy is perceived in schools (questions 4, 5 and 6) and the last is how democracy relates to education for citizenship (questions 7 and 8 ). The questions are as follows:

1. What does democracy mean to you?

2. Do you consider yourself an active democrat? Why?

3. How is this reflected in your daily life? Think about everyday situations

4. Do you think the school is a democratic environment?

5. Did you experience as a student (primary/secondary) that democratic school environment? where and how did you experience it?

6. What are your personal expectations and possible challenges regarding the idea of generating "more democracy in schools"?

7. Do you think that democracy and education for citizenship are related? 


\section{How is democracy and capitalism related?}

Table 1. Category system for information analysis.

\begin{tabular}{|c|c|c|c|}
\hline \multicolumn{4}{|c|}{ 1. Conceptualization of democracy } \\
\hline Subcat. & Variable & Descriptor & Level \\
\hline \multirow{3}{*}{ 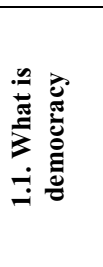 } & $\begin{array}{l}\text { Simple/ ambiguous } \\
\text { vision }\end{array}$ & $\begin{array}{l}\text { It is not clearly defined as a democracy, or different perspectives are } \\
\text { mixed. }\end{array}$ & I \\
\hline & $\begin{array}{l}\text { Theoretical/ } \\
\text { restrictive vision }\end{array}$ & $\begin{array}{l}\text { It provides an institutional vision or definition of democracy, defining some } \\
\text { kind of democracy, linking it to purely political issues (direct, liberal, } \\
\text { Christian-Democratic, representative, popular, etc.). }\end{array}$ & II \\
\hline & \begin{tabular}{|l|} 
Integrated/ \\
Participatory visior
\end{tabular} & $\begin{array}{l}\text { In addition to the institutional aspects, the definition of democracy also } \\
\text { includes the full participation of people in their context in an active and } \\
\text { direct way (political, social, environmental, etc.). }\end{array}$ & III \\
\hline \multirow{3}{*}{ 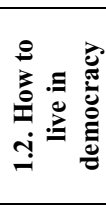 } & $\begin{array}{l}\text { No active } \\
\text { participation }\end{array}$ & Democracy is not involved in people's daily lives & I \\
\hline & $\begin{array}{l}\text { Indirect } \\
\text { participation }\end{array}$ & $\begin{array}{l}\text { Democracy is identified and exercised in specific actions or moments } \\
\text { (political elections, etc.) (representative democracy) }\end{array}$ & II \\
\hline & tive participation & $\begin{array}{l}\text { Democracy as a fundamental principle for people's decision-making in any } \\
\text { aspect of their lives (active and participatory democracy) }\end{array}$ & III \\
\hline \multicolumn{4}{|c|}{ 2. Democracy and School } \\
\hline \multirow{3}{*}{ 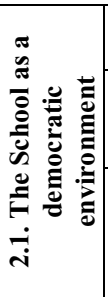 } & Non-democratic & $\begin{array}{l}\text { The school is not a democratic context, so no truly democratic actions are } \\
\text { carried out. }\end{array}$ & I \\
\hline & $\begin{array}{l}\text { Democratic } \\
\text { Guardianship }\end{array}$ & $\begin{array}{l}\text { It appears to be a democratic context but not all people have the same real } \\
\text { decision-making capacity. The actions are apparently democratic but } \\
\text { ultimately must be supervised by the management of the centre. }\end{array}$ & II \\
\hline & $\begin{array}{l}\text { Fully democratic } \\
\text { environment }\end{array}$ & $\begin{array}{l}\text { It is a fully democratic environment. In general, the people involved in } \\
\text { decision-making (teachers, students, parents, etc.), they have the same } \\
\text { capacity. There are governing and management bodies that promote and } \\
\text { ensure democratic participation in the centre. }\end{array}$ & III \\
\hline \multirow{3}{*}{ ヘֶ. } & $\begin{array}{l}\text { No democratic } \\
\text { experiences }\end{array}$ & They have not perceived, as a student, any democratic experience & I \\
\hline & $\begin{array}{l}\text { Punctual } \\
\text { Experiences }\end{array}$ & $\begin{array}{l}\text { Democratic experiences take place at specific times (election of delegates, } \\
\text { etc.). }\end{array}$ & II \\
\hline & $\begin{array}{l}\text { Democratic } \\
\text { experiences }\end{array}$ & $\begin{array}{l}\text { There is a great diversity of experiences in different moments that } \\
\text { demonstrate the regularity in time of this type of actions. }\end{array}$ & III \\
\hline \multirow{3}{*}{ 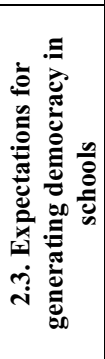 } & Low expectations & $\begin{array}{l}\text { Democracy cannot be generated in schools, because management, } \\
\text { organisational and decision-making issues are imposed by teachers or } \\
\text { regulations. }\end{array}$ & I \\
\hline & $\begin{array}{l}\text { Intermediate } \\
\text { expectations }\end{array}$ & $\begin{array}{l}\text { Despite the impositions of the regulations and management of the centre, } \\
\text { shared decision-making may be included in some governing bodies of the } \\
\text { centre and in specific activities. }\end{array}$ & II \\
\hline & High expectations & $\begin{array}{l}\text { The school must function as a true democratic community (and "open the } \\
\text { doors to society") allowing the democratic intervention of all the agents } \\
\text { that make up the educational centre (teachers, students, PAS, family, etc.). } \\
\text { The decisions taken in the classroom must be shared (choice of } \\
\text { subjects/contents, coexistence, etc.). }\end{array}$ & III \\
\hline \multicolumn{4}{|c|}{ 3. Democracy and Citizenship Education } \\
\hline Subcat. & Variable & Descriptor & Level \\
\hline \multirow{3}{*}{ 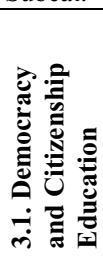 } & $\begin{array}{l}\text { Unrelated or } \\
\text { ambiguous }\end{array}$ & $\begin{array}{l}\text { Democracy is a political issue with some relation to education for citizenship, } \\
\text { but not a determinant one in relation to the other. }\end{array}$ & I \\
\hline & $\begin{array}{l}\text { Simple } \\
\text { relationships }\end{array}$ & $\begin{array}{l}\text { Democracy and its implementation is related to education for citizenship as it } \\
\text { sets certain standards of behaviour for citizens when it comes to living in } \\
\text { society. }\end{array}$ & II \\
\hline & \begin{tabular}{|l|} 
Complex \\
relationships
\end{tabular} & $\begin{array}{l}\text { Democracy and education for citizenship are closely related and influence } \\
\text { each other, as the type of citizen marks and dictates the type of democracy } \\
\text { and vice versa. }\end{array}$ & III \\
\hline \multirow{3}{*}{ ํ. 률 } & Unrelated & $\begin{array}{l}\text { No relations are established since one is a political system and the other is an } \\
\text { economic system. }\end{array}$ & I \\
\hline & \begin{tabular}{|l|l} 
Linear \\
relationships
\end{tabular} & $\begin{array}{l}\text { A linear relationship is established between the two, identifying democracy } \\
\text { with the current system of liberal capitalism. }\end{array}$ & II \\
\hline & \begin{tabular}{|l|} 
Critical \\
Relationships
\end{tabular} & $\begin{array}{l}\text { Complex relations are established between the two, even considering that } \\
\text { capitalism can be an obstacle to the development of an advanced democracy. }\end{array}$ & III \\
\hline
\end{tabular}


Regarding the analysis of the information obtained through the questionnaires, a system of categories has been designed, consisting of three main categories which in turn contain a series of subcategories. In other words, each of these variables has three possible variables that are organized hierarchically through three levels of complexity, from the simplest view to the most complex or developed. In this way, the category system is organised as a progression hypothesis [3]. This system is constituted not only as a reference point for research and for understanding the construction of knowledge in schools but also to guide the teaching-learning processes that take place in this context in a substantiated manner[4],[5],[6]. The category system is presented below (Table 1.)

\section{Results}

To present the results obtained from the analysis of the questionnaires, we focus mainly on the three dimensions proposed by our study. In this way, a series of graphs are presented with the answers inferred from the questionnaires.

\subsection{Conceptualization of democracy}

\section{Q1. What is democracy?}

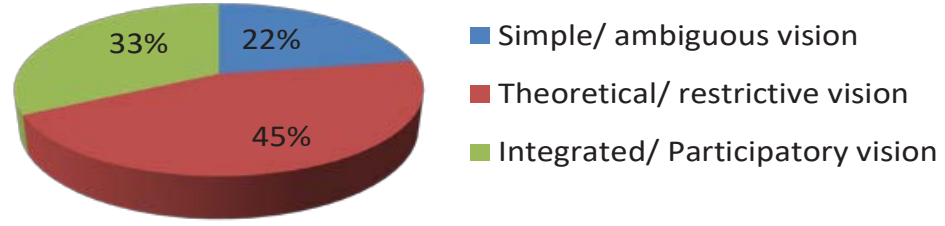

Fig. 1. What is democracy

\section{Q2 y Q3 . How to live in democracy?}

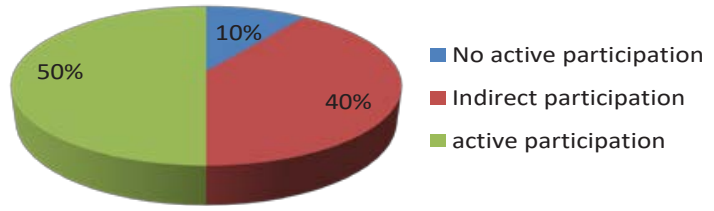

Fig. 2. How to live in democracy

Regarding the conceptualization of democracy, as can be seen in Figure 1, the most chosen option is the "theoretical/restrictive view" (level II) of the concept of democracy. Forty-five percent of respondents define democracy from an institutional perspective, linking it to purely political issues. As an example, subject no. 24, in this perspective, writes the following:

"Democracy means to me the government of the people as well as its etymological meaning in classical Greek. Today we could continue to link it to the same meaning, that is to say, to leave it to the citizens to choose their representatives and the form of government".

However, about the variable how to live in a democracy, the most frequently chosen option is "full and active participation" (level III), where 50\% of those surveyed consider themselves to be active democrats, as they consider this to be a fundamental principle for decision-making in any aspect of their lives. This way, subject 27 indicates the following: 
"I consider myself a democrat because I am tolerant, and I fight for the rights and duties of those around me, accepting all opinions even if they are contradictory to mine.... In work we reach a consensus, by majority, every time we want to decide something. With my friends and family, we discussed different topics when we met, showing first interest and respect"

\title{
3.2 Democracy and school
}

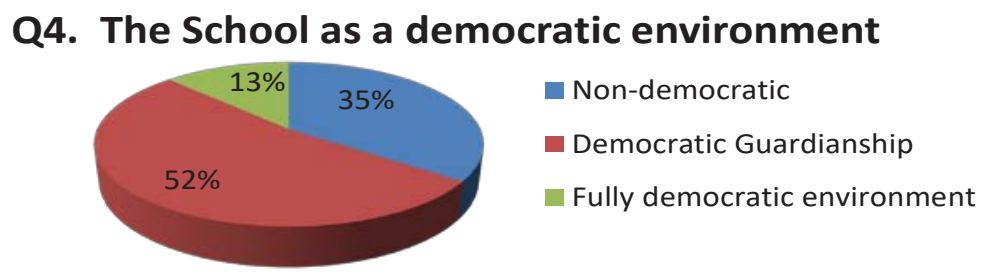

Fig. 3. The School as a democratic environment

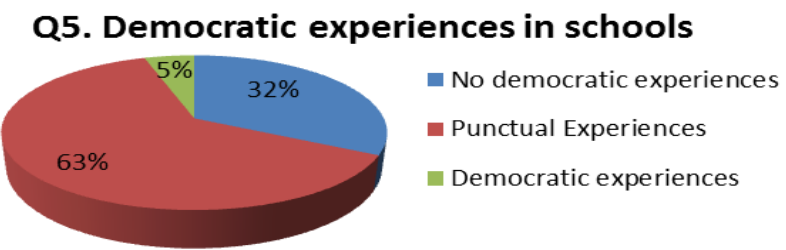

Fig. 4. Democratic experiences in schools

\section{Q6. Expectations for generating democracy in schools}

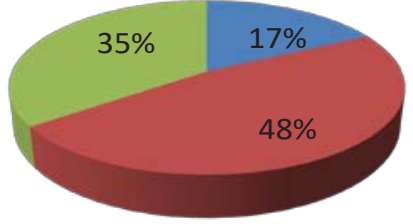

\author{
- Low expectations \\ - Intermediate expectations \\ High expectations
}

Fig. 5. Expectations for generating democracy in schools

With respect to the relationship between democracy and school, we see how the three variables analysed (graphs 3, 4 and 5) stand out in the intermediate or level two of the category system. This is because, in general, the students surveyed characterise the school as a context with a "supervised democracy" (with an allocation of 52\%). This happens because although the school context is apparently democratic, ultimately the decision making is supervised by the teacher or the school management. In addition, they are usually "one-off experiences", as $63 \%$ of the students surveyed indicate, either through the election of a delegate (once per year) or where to go on a field trip, etc. It is also significant that $48 \%$ of students have intermediate expectations regarding the generation of democracy in schools, since they recognize that although there are regulations governing classroom and/or school management, it is possible to include actions that promote greater democratization in the processes of management, coexistence and socialization in schools, with certain limits. We can exemplify these questions with the answers of subject no. 9:

"The school is not always a democratic environment, but it must be, because the school is made up of the entire educational community. The whole group must be listened to because the form and the decisions are made by everyone.... I experienced this democratic 
environment in some subjects, especially in the Integrated Project subjects, where we all chose what we were going to do in the subject... the way of giving the subject and the activities should not be chosen by the teacher, but should be decided by the whole class..."

\subsection{Democracy and citizenship education}

\section{Q7, Democracy and Citizenship Education}

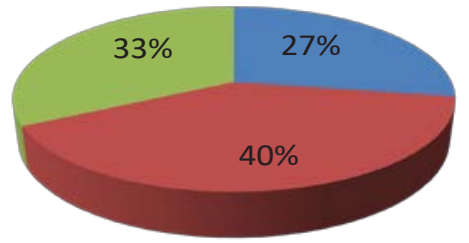

- Unrelated or ambiguous

- Simple relationships

Complex relationships

Fig. 6. Democracy and Citizenship Education

\section{Q8. Democracy and capitalism}

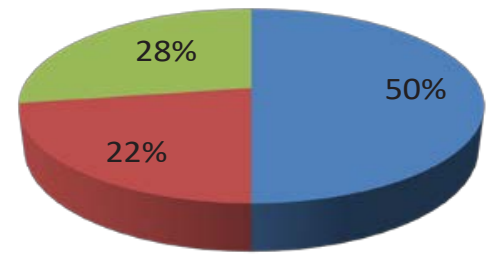

Unrelated

- Linear relationships

Critical Relationships

Fig. 7. Democracy and capitalism

Finally, concerning the relationship established between democracy and citizen education, as well as with capitalism, certain discrepancies can be observed. In category 7 , although the most popular option, with $40 \%$, is again the intermediate option (level II) "Simple Relationships", the other two options are closely followed. Therefore, there is one group $(33 \%)$ with responses at level III or higher, "Complex Relationships", and another group $(27 \%)$ with responses at level I, "Unrelated". This indicates a certain heterogeneity in answering this question, as it is a question that had not been asked before (in their own words) in a rigorous manner. Regarding the question how democracy relates to capitalism, we see for the first and only time that level I (50\%), "No Relationship", predominates over the others. This is because half of those surveyed feel that relationships are not established, as one is a political system and the other is an economic system. For example, subject 35 answers the eighth question with the following statement:

"No, I don't see any connection. They seem different to me."

\section{Conclusions}

It is worth noting that throughout the entire research process, students have shown a great deal of interest in the issues raised, even though they indicate that the issue of education for democracy has never been explicitly addressed during their compulsory training. They point out that they have studied what democracy is, or what its historical origin is, or how it appears and is implanted in certain countries, etc., but always from a theoretical perspective and never from a practical one. 
It is also noted that the concept of democracy they have is not shared. Some students identify democracy with social welfare and the benefits of the state, beyond political or economic issues, while others are practically confined to these two issues.

Some of them have not experienced any democratic situation in the school as students, or do not remember it, which is equally significant. While others do remember in a pleasant way, the election of a delegate or the vote to carry out a specific activity, etc. It is noteworthy that only $5 \%$ of those surveyed remember having carried out regular democratic activities or actions at school. This has a clear relationship with a traditional teaching methodology, where the relations between teachers and students are unidirectional and clearly hierarchical. The teacher is the one who has all the decision-making power in the classroom and shares it with the children or the parents on specific occasions. This issue is of great importance, since it is assumed that schools should provide "in-depth" training for citizenship and democracy, both practical and theoretical.

Finally, regarding the relationship between education for citizenship and democracy, we find a wide variety of answers. There are contributions that indicate that no relationship is established. However, other contributions indicate that education for citizenship and democracy are closely linked, since education for global citizenship must start from a democratic situation for decision-making linked to the constitutional principles of freedom and equality of all people.

\section{References}

1. A. Bolívar, RIEJS, 5 (1), 69-87 (2016).

2. R. Hernández, C. Fernández M.P Baptista. Metodología de la Investigación. (2010).

3. F. Rodríguez-Marín, J. Fernández Arroyo, J.E. García, Enseñanza de las ciencias, 32(3), 303-318. (2014)

4. R. Porlán, R. Martín Del Pozo, A. Rivero, J.Harres, P. Azcárate, and M. PIZZATO, Enseñanza de las Ciencias, 28(1), 31-46. (2010).

5. R. Porlán, R. Martín Del Pozo, A. Rivero, J.Harres, P. Azcárate, and M. PIZZATO, Enseñanza de las Ciencias, 29 (3), 413-426. (2011).

6. C. Martínez, and V.G. Martínez, Nodos y nudos. 32, 50-64. (2012). 